\title{
Biochemical characterization of pink husked coconut types
}

\author{
Regi J. Thomas*, M. Shareefa, H. Harsha and Anitha Karun ${ }^{1}$ \\ ICAR-Central Plantation Crops Research Institute, Regional Station, Kayamkulam-690 533, Kerala, India \\ ${ }^{1}$ ICAR-Central Plantation Crops Research Institute, Kasaragod-671 124, Kerala, India
}

(Manuscript Received: 08-09-2020, Revised: 16-12-2020, Accepted: 15-01-2021)

\begin{abstract}
Coconuts with various traits are available in different coconut growing countries. The pink husk is one such trait that has already been reported in coconut. There is a demand for tender nut water from pink husked types of coconut to treat hepatitis by traditional medicins practitioners. Studies were carried out to characterize pink husked types identified in Guam Tall variety of coconut. There were no morphological differences with respect to the nut characters between pink and non-pink husked types. Biochemical characterization of pink husked types revealed significantly higher total phenol content in the tender nut water of pink husked types than normal husked types. A significantly higher protein content of $86 \mathrm{mg} 100 \mathrm{~mL}^{-1}$ was noted in pink husked type, compared to normal husked type with $58.7 \mathrm{mg} 100 \mathrm{~mL}^{-1}$. Higher free radical scavenging activity based on DPPH assay with pink husked type was recorded with an $\mathrm{IC}_{50}$ value of 266.7 compared to normal type with an $\mathrm{IC}_{50}$ value of 358 . Similarly, phosphomolybdate assay also revealed higher scavenging activity of pink husked type based on the $\mathrm{IC}_{50}$ value of 415.2 compared

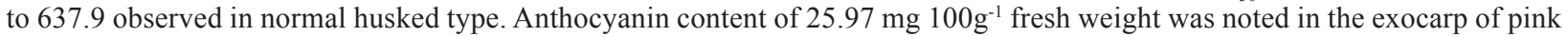
husked types, and it was negligible in normal husked type. These results justify the use of pink husked coconuts in various traditional medicines. There is tremendous potential for exploiting pink husked types of coconut in the pharmaceutical industry.
\end{abstract}

Keywords: Antioxidants, coconut, pharmaceutical properties, pink husked trait, tender nut water

\section{Introduction}

Coconut is a multi-purpose perennial crop grown in the tropics and cultivated in more than 94 countries, covering an area of nearly 12 million hectares (Rethinam, 2019). It is interlinked with the livelihood of millions of people living in coconut growing countries. Coconuts with different traits are available in the germplasm collections available in major coconut growing countries. Germplasm characterization has resulted in the identification and utilization of varieties with different economic uses. However, unexplored diversity still exists in the coconut gene pool, and detailed scientific studies are lacking for certain specific traits, which have already been reported in coconut.

The pink husk is one such trait that has already been reported in coconut from different countries. Sparse occurrence of pink husked types were recorded from the West Coast Tall (WCT) population cultivated in the root (wilt) disease affected tracts of Kerala State, India (Thomas et al., 2016). Such types were also observed in Malayan Green Dwarf(MGD) population cultivated at CDB Farm, Ernakulam (Kerala State) and also from ICAR-CPCRI Regional Station, Kayamkulam (unpublished data). Rarely such trait-specific palms were observed, and hence systematic studies using large samples becomes a constraint. A coconut palm bearing fruits with pink coloured mesocarp was identified in the San Ramon Tall population from ICAR-CPCRI, Kasaragod. Flowers and fruits from all bunches exhibited pink colour below the tepals, and the husk fibres of tender fruits were also of pink colour (Jerard et al., 2016).

Coconut water is used as a beverage for its effective hydrating properties with several healthpromoting abilities (Manna et al., 2014). In Ayurveda, anjana (application of medicines to the

*Corresponding Author: regijacob@yahoo.com 
eye in the form of an ointment) is used to cure ocular problems. Elaneer kuzhambu is formulated in coconut water and is used to reverse cataract formation (Varma et al., 2013). Tender coconut water also relieves pitta (Shubhashree et al., 2014). In Ayurveda, tender coconut water is generally cited as 'pittanashaka', used in the treatment protocol for hepatitis. In Coimbatore and Palakkad districts of Tamil Nadu and Kerala, folk-lore medicines for hepatitis include shell of Turbinella rapa made into a paste with tender coconut water and given twice a day internally. Similarly, a handful of tender leaves of red variety of castor (Ricinus communis L.) are made into a paste mixed in tender coconut water and administered internally to treat hepatitis (Sankaranarayanan, 1988).

There is a demand for tender nut water from pink husked types of coconut, especially for the treatment of hepatitis by traditional medicinel practitioners. This paper describes the biochemical characterization of pink husked types identified in the Guam Tall population at ICAR-CPCRI, Regional Station, Kayamkulam, to validate its antioxidative properties.

\section{Materials and methods}

Pink husked type of coconut was identified from Guam Tall accession planted in the experimental trial on 'Evaluation of tall accessions of coconut for resistance to root (wilt) disease of coconut' planted in 2014 at ICAR-CPCRI, Regional Station, Kayamkulam. Six to seven-month-old tender nuts were collected from such coconut palms for the study from September 2019 to February 2020 .

Morphological character studies: Five palms each from Guam Tall population with normal husk and pink husk were selected, and nut character studies were done based on standard procedure (IPGRI, 1995; COGENT, 2007).

Biochemical characterization: Protein content was estimated by Lowry et al. (1951). Phenol estimation of tender nut water from six to seven-month-old nuts was done based on Singleton and Joseph's modified method (1965). Quantitative determination of free amino acids in tender nut water of same age nuts was done using Ninhydrin test (Moore and Stein 1948).
Estimation of antioxidant activity by DPPH assay: The method of Brand-Williams et al. (1995) was followed with some modifications for estimating DPPH radical scavenging activity. The percentage inhibition was calculated by $\left[\left(\mathrm{A}_{\mathrm{C}}-\mathrm{A}_{\mathrm{S}}\right) / \mathrm{A}_{\mathrm{C}}\right] \times 100$, where $A_{C}$ is the absorbance value of the DPPH solution of the control and $A_{S}$ is the absorbance value of the DPPH solution sample. The radical scavenging activity of DPPH was expressed as IC50, representing the concentration of the extract required to inhibit 50 per cent of the free radical scavenging activity.

Estimating antioxidant activity by phosphomolybdenum assay: Antioxidant activity was also evaluated by the phosphomolybdenum method as per the modified procedure of Prieto et al. (2005). An aliquot of 0.1 to $1.0 \mathrm{~mL}$ of working standard (initially a stock solution was prepared by dissolving $50 \mathrm{mg}$ ascorbic acid in $50 \mathrm{~mL}$ of distilled water, and the working standard was prepared by diluting $5 \mathrm{~mL}$ of stock solution to $100 \mathrm{~mL}$ ) and samples was taken in a series of test tubes followed by the addition of $1 \mathrm{~mL}$ of molybdate reagent solution. The tubes were covered with silver foil and incubated in a water bath at $95^{\circ} \mathrm{C}$ for $90 \mathrm{~min}$. After incubation, samples were cooled to room temperature, and the absorbance was read at 695 $\mathrm{nm}$ against a blank. Ascorbic acid served as the standard in this assay.

Determination of anthocyanin pigment concentration by the $\mathrm{pH}$ differential method: Exocarp of the six to seven-month-old nuts from pink husked types were used in this study. The exocarp was separated from the mesocarp before cutting it into smaller pieces. Determination of total anthocyanin pigment content was done as per Lee et al. (2005). Four different solvents viz., methanol, acidified methanol, ethanol, water were taken separately with $50 \mathrm{~g}$ of sample, and the samples were centrifuged at $10,000 \mathrm{rpm}$ for $10 \mathrm{~min}$. The supernatant was taken for analysis. Determination of the appropriate dilution factor was found out by diluting the sample with a $\mathrm{pH}$ 1.0 buffer until the absorbance at $520 \mathrm{~nm}$ was within the linear range of the spectrophotometer. Using this dilution factor, two dilutions of the sample were prepared, one with a $\mathrm{pH} 1.0$ buffer and the other with a $\mathrm{pH} 4.5$ buffer. 
The absorbance of the samples, diluted with $\mathrm{pH} 1.0$ buffer and $\mathrm{pH} 4.5$ buffer, was measured at both $520 \mathrm{~nm}$ and $700 \mathrm{~nm}$. The diluted sample was read against a blank tube filled with distilled water. Absorbance was taken within 20-50 min of sample preparation. The anthocyanin pigment concentration in the pink husked coconut was calculated and expressed as cyanidin-3-glucoside equivalents. Paired t-test was used to statistically analyse the data to evaluate its significance at different levels $(1 \%$ and $5 \%)$ (Panse and Sukathme, 1985).

\section{Results and discussion}

Morphological features of pink husked types: Guam Tall palms included both green and bronze coloured fruited types. Most of the green fruited palms are pink husked types, whereas bronze fruited types are normal. There was palm to palm variation in the intensity of pink colour in the green fruited types. Some had light pink colour only at the calyx end, whereas some had very intense pink colour at the calyx and mesocarp. Few green fruited types had slight pink colouration even inside the nut. There were no other morphological differences with respect to the size and shape of the nut, quantity of nut water between pink and non-pink husked types in Guam Tall.

Biochemical characterization: Present studies revealed significantly higher total phenol content in the tender nut water of pink husked types than control (Table 1). Higher phenol content is an indication of its ability to scavenge free radicals. Mantena et al. (2003) reported that coconut water possessed antioxidant properties and could scavenge free radicals. Antioxidative properties of coconut water could be attributed to the presence of such contents of phenolic compounds.

There was no significant difference with regard to free amino acid content in both pink husked and normal husked types (Table 1). The developing fruit contains a variety of nitrogenous substances, of which free amino acids constitute a major part. In a maturing nut, the free amino acid contents in the coconut water increased to $16 \mathrm{mg} 100 \mathrm{~mL}^{-1}$, whereas the concentration of bound amino acids does not show any marked change (Baptist, 1956).

Total soluble solids (TSS) of 5.59 per cent was observed in pink husked types compared to normal husked types (5.56 per cent) and was not significantly different (Table 1). Apsara et al. (2007) have reported high TSS in the hybrids COD x WCT (6.58\%) and LCT x COD (6.51\%). TSS increased from the $6^{\text {th }}$ to $8^{\text {th }}$ month of nut development in coconut (Apsara et al., 2007). Since tender nuts of both pink and normal fruit types of Guam Tall were evaluated in the same season and were of the same maturity group, TSS of both types were on par.

A significantly higher protein content of $86 \mathrm{mg}$ $100 \mathrm{~mL}^{-1}$ was noted in pink husked compared to

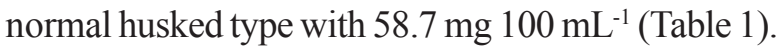
Sinaga et al. (2015) has reported total protein

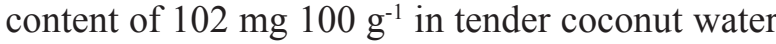
collected from a local variety grown in farmer's plots at Medan, Indonesia, compared to mature coconut water $\left(28 \mathrm{mg} 100 \mathrm{~g} \mathrm{~g}^{-1}\right)$.

Antioxidant activity: The oxidant/antioxidant balance in healthy tissues is maintained with a predominance of antioxidants. A disruption of this balance causes tissue damage. The ability of the

Table 1. Analysis of tender nut water of husk of pink husked types and normal husked types

\begin{tabular}{|c|c|c|c|}
\hline Parameter & $\begin{array}{c}\text { Pink husked } \\
\text { tender nut }\end{array}$ & $\begin{array}{c}\text { Normal } \\
\text { tender nut }\end{array}$ & $\begin{array}{c}\text { Paired } \\
\text { t-test }\end{array}$ \\
\hline Total phenol content $\left(\mathrm{mg} \mathrm{dL}^{-1}\right)$ & 7.01 & 5.08 & $*$ \\
\hline Free amino acids $\left(\mathrm{mg} \mathrm{dL}^{-1}\right)$ & 6.71 & 6.77 & NS \\
\hline Total soluble solids ( ${ }^{\mathrm{O}}$ Brix $)$ & 5.56 & 5.59 & NS \\
\hline Total protein content $\left(\mathrm{mg} \mathrm{dL}^{-1}\right)$ & 86.00 & 58.70 & $*$ \\
\hline Antioxidant activity: a. DPPH assay $\left(\mathrm{IC}_{50}\right.$ value: $\left.\mu \mathrm{g} \mathrm{mL}^{-1}\right)$ & 266.67 & 358.27 & NS \\
\hline 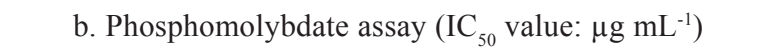 & 415.17 & 637.90 & $* *$ \\
\hline Anthocyanin content in husk (mg $100 \mathrm{~g}^{-1}$ fresh wt.) & 25.97 & 1.46 & $* *$ \\
\hline
\end{tabular}

* Significant at 5\% ** Significant at $1 \%$ 
natural antioxidant to scavenge the DPPH free radical will be measured by the reduction in absorbance by UV-visible spectrum at the wavelength of $517 \mathrm{~nm}$, and the $\mathrm{IC}_{50}$ value is the concentration of antioxidant components in the sample that could show 50 per cent inhibition activity of the DPPH free radicals. $\mathrm{IC}_{50}$ value is the concentration of antioxidant components in the sample that could show 50 per cent inhibition activity of the DPPH free radicals, indicated in the unit $\mathrm{mg} \mathrm{L}^{-1}$. Hence, if a lower concentration of the sample is required for half $(50 \%)$ maximum inhibitory action, the sample has higher antioxidant activity. A higher $\mathrm{IC}_{50}$ value indicates lower radical scavenging activity. Present studies revealed higher scavenging activity based on DPPH assay with a pink husked recording $\mathrm{IC}_{50}$ value of 266.7 compared to normal type with an $\mathrm{IC}_{50}$ value of 358.3. Similarly, the phosphomolybdate assay also revealed higher free radical scavenging activity of pink husked type based on the $\mathrm{IC}_{50}$ value of 415.2 compared to 637.9 observed in normal husked type (Table 1). Tender nut water can act as electron donors due to the presence of phenolic compounds present in it, which justifies its free radical scavenging activity.

Kalina and Navaratne (2018) studied the antioxidant activity of tender mesocarp of two coconut varieties, viz., King Coconut and Young Coconut. They reported that $\mathrm{IC}_{50}$ were $360.1 \mathrm{mg} \mathrm{L}^{-1}$ and $448.4 \mathrm{mg} \mathrm{L}^{-1}$ respectively for tender mesocarp of King and Young Coconut, indicating that King Coconut had higher antioxidant activity than the Young Coconut. They also analysed the antioxidant activity of tender coconut mesocarp under different treatments to develop a food product from mesocarp. The results revealed that the highest antioxidant activity was recorded for blanched-solar dried mesocarp from King Coconut (421.8 $\mathrm{mg} \mathrm{L}^{-1}$ ) and the lowest for unblanched-cooled with dehumidified mesocarp from Young Coconut (856.7 $\mathrm{mg} \mathrm{L}^{-1}$ ) (Kalina and Navaratne, 2019).

Anthocyanin content: In the present study, anthocyanin content of $25.97 \mathrm{mg} 100 \mathrm{~g}^{-1}$ fresh wt. was noted in the exocarp of pink husked types, and it was negligible in normal husked type (range: 0.00-1.46 mg $100 \mathrm{~g}^{-1}$ fresh wt). The anthocyanin content in coconut testa varied between $17.2 \mu \mathrm{g}$ to $569.2 \mu \mathrm{g} \mathrm{g}^{-1}$ (Arivalagan, 2017). Steed and Truong (2008) had reported higher anthocyanin content (51.5 and 174.7 $\mathrm{mg} 100 \mathrm{~g}^{-1}$ fresh wt.) and higher antioxidant activity in purple fleshed sweet potatoes (PFSP), which have been utilized as a healthy food commodity in Asia. The presence of higher anthocyanin content also can be correlated to higher antioxidant activity.

\section{Conclusion}

The present investigation based on biochemical characterizations revealed significantly higher antioxidant activity and anthocyanin content in pink husked coconut types. These results justify the use and demand for pink husked coconuts for therapy and their use in various traditional medicines. Detailed studies by undertaking liver function studies in mammals are suggested to validate the scientific basis for using pink husked types for therapeutic utilization. Preliminary studies indicate the tremendous potential for exploiting pink husked types of coconut in the pharmaceutical industry.

\section{References}

Apsara, S.E., Arunachalam, V., Jayabose, C. and Kumaran, P.M. 2007. Evaluation of coconut hybrids for tender nut purpose. Indian Journal of Horticulture 64(3): 314-319.

Arivalagan, M. 2017. Biochemical and nutritional evaluation of coconut Cocos nucifera $\mathrm{L}$ haustorium and its co-products. Ph.D. Thesis. Department of Biochemistry and Molecular Biology, Central University of Kerala, Kasaragod pp. 141.

Baptist, N.G. 1956. L-amino acid and other free amino acids in the coconut. Nature (London) 178: 1403-1404.

Brand-Williams, W., Cuvelier, M. E. And Berset, C. 1995. Use of a free radical method to evaluate antioxidant activity. LWT - Food Science and Technology 28(1): 25-30.

COGENT. 2007. Minimum list of descriptors for coconut. International Coconut Genetic Resources Network http:/ /www.cogentnetwork.org Cited $4^{\text {th }}$ Feb 2010.

IPGRI. 1995. Descriptor for coconut (Cocos nucifera L.). International Plant Genetic Resources Institute, Rome, Italy, 61p.

Jerard, B.A., Niral, V., Samsudeen, K. and Gayatri. U.K. 2016. Pink husked coconut selection - A trait of promise. In: ISOCRAD-3 (Eds.) Chowdappa, P., Muralidharan, K., Samsudeen, K. and Rajesh, M.K. 10-12 December 2016, ICAR-CPCRI, Kasaragod (Abstracts) pp. 21.

Kalina, S. and Navaratne, S.B. 2018. Evaluation of antioxidant activity and texture profile of Tender- Young and King coconut (Cocos nucifera) mesocarp. Journal of Pharmacognosy and Phytochemistry 7(3): 2945-2949. 
Kalina, S. and Navaratne, S.B. 2019. Analysis of antioxidant activity and texture profile of Tender - Young and King coconut (Cocos nucifera) mesocarps under different treatments and the possibility to develop a food product. International Journal of Food Science. https://doi.org/ 10.1155/2019/7470696.

Lee, J., Durst, R.W. and Wrolstad, R.E. 2005. Determination of total monomeric anthocyanin pigment content of fruit juices, beverages, natural colorants, and wines by the $\mathrm{pH}$ differential method: collaborative study. Journal AOAC International 88: 1269-1278.

Lowry, O.H., Rosbrough, N.J., Farr, A.L. and Randall, R.J. 1951. Protein measurement with the folin phenol reagent. Journal of Biological Chemistry 193: 265-275.

Manna, K., Khan, A., Das, D.K., Kesh, S. B., Das, U., Ghosh, S., Dey, R.S., Saha, K.D., Chakraborty, A., Chattopadhyay, S., Dey, S. and Chattopadhyay, D. 2014. Protective effect of coconut water concentrate and its active component shikimic acid against hydroperoxide mediated oxidative stress through suppression of NF$\kappa \mathrm{B}$ and activation of Nrf2 pathway. Journal of Ethnopharmacology 155: 132-146.

Mantena, S.K., Jagadish, Badduri, S.R., Siripurapu, K.B., Unnikrishnan, M.K. 2003. In vitro evaluation of antioxidant properties of Cocos nucifera L. water. Nahrung 47(2):126-131. doi: 10.1002/food.200390023.

Moore, S. and Stein, W.H. 1948. Photometric ninhydrin method for use in the chromatography of amino acids. Journal of Biological Chemistry 176: 367-388.

Panse, V.G. and Sukhatme, P.V. 1985. Statistical Methods for Agricultural Workers. Indian Council of Agricultural Research, New Delhi. 359 p.

Prieto, P., Pineda, M. and Aguilar, M. 2005. Spectrophotometric quantitation of antioxidant capacity through the formation of a phosphomolybdenum complex: Specific application to the determination of vitamin E. Analytical Biochemistry 269: 337-341.
Rethinam, P. 2019. International scenario of coconut sector. In: The Coconut Palm (Cocos nucifera L.) - Research and Development Perspectives. (Eds.) Nampoothiri, K.U.K., Krishnakumar, V., Thampan, P.K. and Nair, M.A., Springer International Publishing AG Switzerland, pp. 21-56.

Sankaranarayanan, A.S. 1988. Folk-lore medicines for jaundice from Coimbatore and Palghat Districts of Tamil Nadu and Kerala, India. Ancient Science of Life 7(3 \& 4): 175-179.

Sinaga, S.M., Margata, L. and Silalahi, J. 2015. Analysis of total protein and non protein nitrogen in coconut water and meat (Cocos nucifera) by using Kjeldahl method. International Journal of Pharmtech Research 8(4): 551-557.

Singleton, V.L. and Joseph, A.R. Jr. 1965. Colorimetry of total phenolics with phosphomolybdic-phosphotungstic acid reagents. American Journal of Enology and Viticulture 16(3): 144-158.

Shubhashree, M.N., Venkateshwarlu. G. and Doddamani. S.H. 2014. Therapeutic and nutritional values of narikelodaka (tender coconut water) - A review. Research Journal of Pharmacognosy and Phytochemistry 6(4): 195-201.

Steed, L.E. and Truong, V.D. 2008. Anthocyanin content, antioxidant activity, and selected physical properties of flowable purple fleshed sweet potato purees. Journal of Food Science 73(5): S215-S221. https://doi.org/10.1111/ j.1750-3841.2008.00774.x.

Thomas, R.J., Aswathy, L., Gopal, S., Sreelekshmi, J.S. and Shareefa, M. 2016. Characterization of pink husked selection of coconut (Cocos nucifera L.) In: XXII PLACROSYM, 15-17 $7^{\text {th }}$ December 2016, ICAR-CPCRI, Kasaragod, Kerala (Book of Abstracts) pp. 80.

Varma, R.K., Manjusha, R., Harisha, C. R. and Shukla, V.J. 2013. Pharmacognostical and physicochemical analysis of Elaneer Kuzhambu - An ayurvedic polyherbal formulation. International Journal of Pharmacy and Life Sciences 4(2): 2402-2406. 